\title{
Cranmer and the Controversy Surrounding Publication of Certayne Sermons or Homilies (1547)
}

\section{Ronald B. Bond}

The attempt of the English church during the sixteenth century to vindicate Henry's split with Rome was, of course, a long and gradual process toward viable Anglicanism, a process which included translations of the scriptures and some ancillary texts such as Erasmus' Paraphrases into the vernacular, the formulation of a new service of worship contained in the Book of Common Prayer, the evolution of what came to be the ThirtyNine Articles and the welding together of sacred and secular power in the person of the monarch, whether he be called Supreme Head or Supreme Governor of the native church. In addition, the church - if we can use that collective term to refer to Cranmer, Jewel, Parker, Hooker, Whitgift and other learned and lesser men who effectively exercised both religious and political influence - produced several formal justifications of the course which it was charting, the most memorable of which are Jewel's Apologia Ecclesiae Anglicanae (1562) and Hooker's Laws of Ecclesiastical Polity (1593). The doctrinal compromise eventually achieved, however, was not won easily. To the parishioner in his uncomfortable pew, adherence to a new and distinctive sort of Christianity meant accepting, sometimes reluctantly, the doctrinal and liturgical reforms worked out by men who understandably sought to impose their sophisticated views on people far less educated in the subtleties of theological thought and far more emotionally committed to the religion in which they had been raised.

How to instruct the nation in the doctrinal changes crucial to protestantism became then a principal question for the early English reformers. Uniformity and consistency of belief were obviously desirable and in an atmosphere where not even bishops could agree on just who were protestants and who papists, these goals could be reached only by emphasizing standardized methods of religious tuition. Successive convocations, for instance, urged that a strictly protestant grammar book be used in the schools so that young children would not be tainted with the slightest inkling of the "popish" beliefs. ${ }^{1} \mathrm{~A}$ far more important result, however, of the need felt for religious uniformity was the role given preaching, a relatively minor aspect of the old religion, which was recognized by English and continental reformers alike to be a major part of the new service and a primary instrument for popular religious instruction. But the reformers' attempts to use the pulpit effectively had first to contend with the shortage of qualified preachers and the abundance of men who could preach, but who could not in conscience comply with the proposed doctrinal changes. Consequently, as a response to the need which Cranmer and the other Henrician reformers saw for nation-wide assimilation of particularized protestant beliefs, the first book of homilies was conceived. My purpose is to describe the history of these homilies and some contemporary reactions to them, since historians of sixteenth century religious thought, perhaps because references are widely dispersed, have not given them the attention they seem to deserve.

Archbishop Cranmer, fresh from his efforts on behalf of the Matthews Bible and the Great Bible, was at work on sermons in the vernacular as early as 1539 . A letter of that 
year from John Butler and other English churchmen to Conrad Pellican and the Helvetian reformers states that the archbishop "is now wholly employed in instructing the people and in composing discourses in English, which our clergy are to use instead of those Latin ones which they have hitherto prated in their churches like so many parrots." 2 The first great task of the English church was to make the scriptures available to all men; the second was to provide edification which the clergy, many of them with small Latin, could convey to their even less well educated congregations.

There were men, however, "for whom Latin was the living language of learning and religion [and who] feared to desecrate words fraught with the sacred associations of centuries." 3 Such was Stephen Gardiner, Bishop of Win chester, a conservative reformer, often called a Roman Catholic by modern historians, who in the convocation of 1542 presented a list of ninety-nine words from the Vulgate which he considered too significant to change. ${ }^{4}$ The battle lines between Cranmer and Gardiner were clearly drawn: the one believed firmly in the accessibility of all to the scriptures and ecclesiastical writings, the other felt with equal conviction that certain words would be unnecessarily prophaned if tradition were disregarded. On this as on the other issues over which they argued, Cranmer can be characterized as an innovator who sought the best way to impel the common people to religious zeal and theological rectitude; Gardiner, as the cautious reactionary adamant about preserving the old mysteries against the onslaught of mere expediency.

In the same year of 1542 when Gardiner put forward his list of sacred words, Cranmer, who had perhaps originally planned to write a complete series of sermons in the vernacular, proposed that the bishops undertake jointly the burden of producing homilies "for stai of such errours as were then by ygnorant preachers sparkeled among the people." 5 Gardiner, somewhat surprisingly, agreed to this plan, but since it did not receive royal approval it was dropped. We have no record of the projected homilies for the period from 1542-1547. In the meantime, however, the King's Book (1543) was published and the credal statements contained therein subscribed to by both Gardiner and Cranmer.

In the months following Henry's death on January 28, 1547 Cranmer revived the defunct plan for homilies and wrote to Gardiner asking him to contribute one. Gardiner, pleased that the King's Book had settled, for him at least, the debates over the real presence, justification, and the species of the sacraments, refused, and maintained emphatically that homilies were superfluous since "God gave our late soverayne lorde the gyfte of pacificacion in those matters, which, establyshed by his Hyghnes authoryty in the Convocacion, extynguished our devises [plans for homilies] , and remayneth of force with your Grace." 6 He broadcast his criticisms of the proposal in long letters not just to Somerset, but to Cranmer himself, and although Cranmer's letters have not survived, we can reconstruct the main points in the controversy from Gardiner's alone. Cranmer apparently had indicated that the homilies ought to clarify the doctrine of justification, a doctrine whose handling in the King's Book he deemed ambiguous. On this contentious point Gardiner accused Cranmer of hypocrisy, reminding him that he had assented to the book in 1543 and had caused it to be read in his diocese for the past four years. Against Cranmer's claim that English congregations were fed up with the vestiges of medieval sermons, the Legenda Aurea and Mirk's Liber Festivalis, Gardiner retorted on two fronts. He asserted his ignorance of the Legend and the Festival and with considerable equivocation continued: "And I thinke not impossible but there may be in them many foolish, lying tales; and I would wish Christ's religion cleansed and purged from all tales, but so as Christ said, as with the cockle the 
wheat were not pulled up by the root also."7 Gardiner was also dubious that the people should be any more attentive to new sermons than they had been to the old: ". . such as be most rude ... be after led to good lyfe by imitation rather than hearing. They move in the body of the church with much simplicity. And when they have heard words spoken in the pulpit they report they were good and very good and wondrous good ... but what they were ... they cannot tell ...."8 Finally, he attacked the capacity of preaching to promote consistent doctrine. Among the people "yt is a common fation to aske who preacheth, so as the awdyence encreasyth by the man that preacheth, and not by the matter." ing which nonetheless attracts congregations of less than twenty. Rather than consistency, then, homilies written by several hands could only result in

... contencion and altercacion, without al frute or edification. And thusmoch for example of trouble in homylies, which thiese fyue yeres have rested without any buysines, and the people wel doon their dueties, I trust, to God in heven, and knowe wel to ther souverain lord in earth. And our souverain lord that governed them without thiese omylies, goen to heven, whither, I trust we and the people shall goo after, although we trouble them with noo homilies. ${ }^{10}$

Scintillating with trenchant wit and subtle casuistry, these letters brighten the dullness which surrounds the homilies for many historians and show just how seriously their inception was taken in the 1540's.

On July 31,1547 , Gardiner's protests notwithstanding, the king's official printer, Richard Grafton, brought out Certayne Sermons, or bomilies, appoynted by the kynges Maiestie, to be declared and redde, by all persones, Vicars, or Curates, euery Sondaye in their cburches, where they baue Cure. The book contains twelve homilies, the third, fourth and fifth of which were written by Cranmer. These are the central sermons theologically, as they deal with salvation, faith and good works. Cranmer declares that faith alone is necessary and sufficient for salvation, but in trying to accommodate to some degree the Catholic teaching, he further states that good works spring from a lively faith and that no truly Christian man can avoid performing charitable actions emanating from his faith. Thomas Becon, Cranmer's chaplain, wrote the sermon excoriating whoredom and adultery and John Harpesfield wrote of the misery of mankind. Tentative attributions for the other sermons assign homilies on the reading of holy scripture and on the fear of death to Cranmer; "Against Swearing and Periury" to Becon, whose condoning of oathtaking was anathema to the Anabaptists; "Of Christian Love and Charity," the most Roman Catholic in its tendencies, to Bishop Bonner; and "Against Strife and Contention" to Latimer. The authors of the homilies on obedience and on the declining from God have not been identified. It is likely, nonetheless, that Cranmer exerted a controlling hand over them all. ${ }^{11}$

To enforce the reading of these homilies, the thirty-second of the Injunctions, ${ }^{12}$ published on the same day as the homilies, stated that

... because through lack of preachers in many places of the king's realms and dominions, the people continue in ignorance and blindness, all persons, vicars and curates shall read in their churches every Sunday one of the homilies, which are and shall be set forth for the same purpose by the king's authority, in such sort as they shall be appointed to do in the preface of the same. ${ }^{13}$ 
The instructions of the preface to which this injunction refers command parsons to read them

... playnly and distinctely, in suche ordre, as they stande in the boke, (except any Sermon bee preached) and then for that cause onely and for none other, the reading of the sayde Homelie, to be differed vnto the nexte Sondaye folowyng. And when the foresayde boke of Homelies is redde ouer, the Kynges Maiesties pleasure is, that the same be repeted \& redde agayn, in suche lyke sorte, as was before prescribed, vnto such tyme as his graces pleasure shall further be knowen in thys behalfe. ${ }^{14}$

Mandatory for all parishes, to be read again and again, the homilies were the fulfillment of Cranmer's plan to impose upon all of England a standard set of beliefs. As Rickey and Stroup have said in their introduction to a facsimile reprint of the sermons, "these Homilies were probably, next to the Book of Common Prayer, as well known and as influential as any writings produced between 1547 and $1640 . " 15$ We turn now to the reception of the homilies and to the controversies which they continued to provoke.

Churchwardens immediately began to procure the book for their parishes at the cost, according to the records of St. Ewen's, Bristol, of 1 s. 8 d.16 The printers strained to keep up with the demand in these early years: Grafton published two separate editions in 1547, one in each of 1548 and 1549; Whitchurche produced an edition on August 20, 1547 and separate issues bearing the dates August 20 and November 5, 1547.17 Both Whitchurche and Jhon Oswen, whose shop was in Worcester, brought out editions in 1549 . By 1687 , the first book of homilies had appeared in twenty-two editions.

The homilies were virtually the only discourses delivered from English pulpits, for the King was quick to send unambiguous threats to the Bishops which said

that they should not at any time or place preach, or set forth unto the people, any doctrine contrary or repugnant to the effect and intent contained or set forth in the King's highness' homilies; neither yet should admit or give license to preach to any within their diocese, but to such as they should know or at least assuredly trust, would do the same; and if at any time, by hearing or by report proved, they should perceive the contrary, they should then incontinent not only inhibit that person so offending, but also punish him, and revoke their license. ${ }^{18}$

This injunction along with visitation articles ${ }^{19}$ which specifically inquired whether preachers had in fact been reading the homilies ought to have been a successful deterrent to recalcitrant Catholics and independent thinkers. But imposition of the homilies continued to be difficult. In April, 1548, a royal proclamation stipulated that, the homilies excepted, no sermons could be delivered unless the preacher so doing were licensed by the King, Somerset, or Cranmer. A month later, the king forbade licensed preachers themselves

. . to preach or stir the people in open and common preachings of sermons, by any means, that the devout and godly homilies might the better in the meanwhile sink into his subjects' hearts, and be learned the sooner, the people not being tossed to and fro with seditious and contentious preaching, while every man according to his zeal, some better, some worse, goeth about to set out his own fantasy, and to draw the people to his opinion. 20 
The struggle which Cranmer had waged to get the homilies written and published was now succeeded by an even more serious one to get them accepted.

The resistance was headed, naturally, by Gardiner, still Bishop of Winchester, who had opposed the homilies in principle and who now became the chief adversary of the published book. Writing, in Somerset's absence, to the Privy Council, Gardiner laid out his case with curt simplicity, basing his objections on the incompatibility of the Homilies with the King's Book. ${ }^{21}$ Neither could Gardiner understand how priests could be expected to reconcile the numerous discrepancies between the teachings of the Homilies and the Paraphrases on the Gospels, both of which the Injunctions had made required reading. "The booke of the homelies teacheth faith to exclude charitie in the office of justification. Erasmus Paraphrasi teacheth faith to have charitie joyned with him in justification. The boke of homelies teach eth how men may swere. The Paraphrasis teacheth the contrarie verye extremlye."22 Gardir er's analysis of inconsistencies, "as contrarye as "includethe' is contrarie to 'excludethe", goes on to censure mistranslations of the fathers, misinterpretations of the scriptures, and diverse teachings on remission of sin and on the reverence of bread, palms and candles. In a second letter, he offered a new reason for his refusal to comply with the injunctions and his rejection of the homilies: the King's Book had been sanctioned by an act of parliament and to hold views in opposition to it, views such as the Homilies were promulgating, was clearly illegal. Since Gardiner was a man of immense importance, the council, not wishing him to spread dissent further, had to put him in prison, as it also put Bonner, who later recanted his opposition and accepted the homilies. Gardiner's protests were protests he would have written, he says, with the blood of his heart, could he have done so, and although they brought him into favour with Mary, they almost made him a martyr under Edward.

Although Cranmer had to contend at home with Gardiner's animosity and with the problems of getting preachers to restrict themselves to reading only the homilies from their pulpits, heartening news came from abroad. Martin Bucer, the Strassbourg reformer with whom Cranmer had been on friendly terms for several years, published in 1548 his Gratulatio Martini Buceri ad ecclesiam Anglicanum. ${ }^{23}$ Bucer was encouraged by the direction in which the homilies convinced him the English church was moving.

For it chaunced now of late dayes that youre sermons or Homelies came vnto oure handes, wher with ye godlye \& effectiouslye exhorte your people to the reading of holye scripture, and therin expounde to the same the faithe (wherby we holde our christianitie, \& justification wherevpon al oure healthe consisteth and other most holye principles of our religion, with a most godly zeale. [sic] For these foundations truely layde, what may then longe after wane in your churches to the ful perfection of Christ hys doctrine and discipline. (sig. $\mathrm{Ai}^{\mathrm{v}}$ )

Not fully aware perhaps of the contentions and altercations surrounding Cranmer, he says that the restitution of religion effected by the homilies meant that "there can remaine for no long season any remnant of the olde leuen in anye parte of the ceremonyes or discypline (sig. Aiv) Bucer's Gratulatio is a general commendation of the homilies which is specific only when lauding the theory of justification the English had adopted. Bucer may very well, in fact, have been congratulating the English church on deciding to uphold a doctrine very like his own. According to William Haugaard, "these instructional sermons expressed a theo 
logical orientation far closer to that of the continental reformers than the teaching of any book previously authorized in England."24

The ordinary parishioner, meanwhile, was likely unfamiliar with the debates which publication of the homilies inspired. But behavior during the reformed service was as indecorous as Gardiner had predicted it would be. Visitation articles asked "whether any have used to commune, jangle and talk in the church" during the reading of the homily and common prayer and one of Ridley's injunctions charged wardens to be vigilant against "buying, selling, gaming, outragious noise or tumult or any other idle occupying of youth in the church, church-porch or churchyard during the time of common prayer, sermon, or reading of the homily." 25 This restlessness is quite explicable. The unlicensed preachers who were permitted to read the homilies were not always fluent readers, as Spenser's sardonic comment in "Mother Hubberds Tale" illustrates:

For read he could not euidence, nor will,

Ne tell a written word, ne write a letter,

Ne make one title worse, ne make one better:

Of such deep learning little had he neede,

Ne yet of Latine, ne of Greeke, that breede

Doubts mongst Diuines, and difference of texts,

From whence arise diuersitie of sects,

And hatefull heresies, of God abhor'd:

But this good Sir did follow the plaine word,

Ne medled with their controuersies vaine.

All his care was, his seruice well to saine,

And to read Homelies vpon holidayes:

When that was done, he might attend his playes:

An easie life, and fit high God to please (11. 382-395). ${ }^{26}$

When Elizabeth came to the throne, she instructed that "all ministers and readers of public prayers, chapters, and homilies shall be charged to read leisurely, plainly, and distinctly; and also such, as are mean readers, shall peruse over before, once or twice the chapters and homilies, to the intent they may read to the better understanding of the people."27 And although the repetition, Sunday by Sunday, year by year, of the same material was designed to imprint the homilies on the hearts of those who heard them, congregations must be pardoned if in the fold insidious Boredom lurked, a wolf cloaked in piety. For the homilies are written in a plain style and are, in the main, devoid of the zest and piquancy which characterized the sermons of Latimer and perhaps other preachers of the time whose work is not extant. And this plainness of style, though conducive to ready understanding, must have grown wearisome. Ironically, Latimer himself, as an old man, gives us the best contemporary account of how the church at large reacted to incessant exposure to the Certayne Sermons in a description unprejudiced by his possible authorship of one of them. Preaching before the King he says:

Some call them homelies, and indeed so they may be well called, for they are homely handled. For though the priest read them never so well, yet if the parish like them not, there is such talk and babbling in the church that nothing can be heard; and if the parish be good and the priest naught, he will so hack it and chop it, that it were as good for them to be without it, for any word that shall be understood. And yet (the more pity) 
this is suffered of your Grace's bishops, in their dioceses, unpunished. But I will be a suitor to your grace, that ye will give your bishops charge ere they go home, upon their allegiance, to look better to their flock, and to see your Majesty's Injunctions better kept. 28

Perhaps Shakespeare's parish was one which Latimer would have described thus, for after Celia's long speech in As You Like It, Rosalind says, "O most gentle Jupiter [often emendec to 'pulpiter'] what tedious homily of love have you wearied your parishioners withall, and never cried, 'Have patience, good people"'. (III. ii. 149)

The subsequent history of the Edwardian homilies need only be treated briefly here. During Cranmer's lifetime controversy continued over the doctrinal substance of the book, particularly over the relationship of justification to good works. In 1549 and 1550 , Bucer, now living in England, enraged Dr. John Young, later Master of Pembroke Hall, by asserting in a public disputation that "the good works which any seem to do before justification have the nature of $\sin . " 29$ In the ensuing exchange, Bucer enlisted against Young the support of the homilies' teaching and Young was eventually forced to concede that he was "pressed hard" with the homilies even though he had previously subscribed to them. We see here that after only three years some regarded the homilies as statements of official doctrine.

Mary's ascension to the throne brought an end to such open debates, for by royal proclamation the homilies were suppressed. Her visitation articles of 1554 demanded "whether there be any printer or seller of books that hath since the beginning of the queen's majesty's reign printed or sold the books of the schismatical and slanderous communion, the like homilies, and such other books, having in them heretical and damnable opinions . ..."30 Mary, however, and her papal legate, Reginald Pole, recognized the value of homilies for maintaining orthodoxy. Pole's Constitutiones decree that since inexperienced preachers prevailed, homilies should be read, and the Roman Catholics' scheme for supplanting the Edwardian homilies was to include four books of their own sermons. The first was to confute the errors of protestantism; the second was to comprise disquisitions on the Creed, the Ten Commandments, the salutation of the Virgin, and the sacraments; the third was to commemorate the Saints' days; and the fourth was to contrast the virtues with the vices and explain the rites of the church. This plan was never completed, although appended to Bonner's Catechisme (1555) are several homilies composed by Pendleton and Harpesfield. ${ }^{31}$

When Elizabeth reinstated the Edwardian homilies in 1559 - she added a second book in 1563 - their position as approved declarations of doctrine was finally secure. During Elizabeth's reign, they withstood attacks by Puritans such as Fulke and Cartwright who wanted preaching to be more concerned with the everyday problems of England and who felt that individual preachers should be given more latitude in interpreting the Word of God according to their own consciences. They remained important even though they were burned during the Northern Rebellion of 1569 , which itself occasioned the famous "Homily Against Wilful Disobedience and Rebellion." In spite of all controversy, Cranmer had been successful in imposing upon the priests and people of the English Church the homely homilies. We cannot know whether the Christian faith in England was sustained by the homilies or by the more fervent words of the few pulpit orators who were allowed to preach as they saw fit. But without questioning Cranmer's religious sincerity, we can say that in trying to push England toward religious consensus his issuing of the homilies was politically astute. "Well might the souls of weak Christians be faint and feeble, having no warm meat, but 
the cold homilies allowed them. But statesmen easily excuse the matter, finding the juncture of time falling out when many popish pulpits sounded the alarum . . . "32

The University of Calgary

\section{Notes}

See William Nelson, "The Teaching of English in Tudor Grammar Schools," SP, 49 (1952), 117-43.

See Original Letters Relative to the English Reformation, ed. Hastings Robinson, Parker Society, Vol. 53, Pt. 2 (Cambridge: Cambridge University Press, 1847), p. 626.

James A. Muller, Stephen Gardiner and the Tudor Reaction (New York: Macmillan, 1926), p. 104.

For a complete list of these words, see Thomas Fuller, The Cburch History of Britain, ed. J. S. Brewer, 6 vols. (Oxford: Oxford University Press, 1845), III, 199-200.

5 The Letters of Stepben Gardiner, ed. James A. Muller (Cambridge: Cambridge University Press, 1933), p. 296; unreliable texts of some of these letters are found in John Strype, Memorials of Thomas Cranmer, 4 vols. (Oxford: Ecclesiastical History Society, 1848).

6 Gardiner, Letters, p. 296.

Gardiner, p. 312.

Gardiner, p. 311.

Gardiner, p. 356.

Gardiner, p. 310.

These attributions I take from Philip Hughes, The Reformation in England, 3 vols. (London: Hollis and Carter, 1952-54), II, 95; Hughes, in turn, relies on J. T. Tomlinson, The Prayer Book, Articles and Homilies: Some Forgotten Facts about their History (London: E. Stock, 1897), Pp. 232-35.

Hughes mistakenly says "twenty-third": II, 92.

Edward Cardwell, Documentary Annals of the Reformed Cburcb of England, 2 vols. (Oxford: Oxford University Press, 1839), I, 19.

Certayne Sermons, or bomelies (London: Grafton, 1547), sig. $\mathrm{Aii}^{\mathrm{r}}-\mathrm{Aiii}^{\mathrm{V}}$.

Certaine Sermons or Homilies, introd. Mary Ellen Rickey and Thomas B. Stroup (1623; facs. rpt. Gainseville, Florida: Scholars' Facsimiles and Reprints, 1968), viii.

16 The Church Book of St. Ewen's, Bristol 1454 1584, ed. Betty R. Masters and Elizabeth Ralph (Bristol: Publications of the Bristol and Gloucestershire Archaeological Society, Records Section, 1967), p. 183.

17 As R. B. McKerrow points out, however, false dates on official religious publications were common: see $A n$ Introduction to Bibliograpby (Oxford: Clarendon, 1949), p. 203.

18 Cardwell, I, 32.

19 Cardwell, I, 55.

20 Cardwell, I, 64.

21 Gardiner, Letters, pp. 361-372.

22 Gardiner, p. 381.

23 (Basle, 1548); trs. Sir Thomas Hoby, The gratulation ... of Martin Bucer (STC 3963).

24 Elizabeth and the English Reformation: The Struggle for a Stable Settlement of Religion (Cambridge: Cambridge University Press, 1968), p. 16; see also Constantin Hopf, Martin Bucer and the English Reformation (Oxford: Basil Blackwell, 1946), pp. 81-87.

25 Cardwell, I, 58 and 96.

26 Spenser: Poetical Works, ed. J. C. Smith and E. De Selincourt (London: Oxford University Press, 1965), p. 499.

27 Cardwell, I, 231.

28 "Second Sermon Preached Before King Edward the Sixth" (1549) in Sermons, ed. G. E. Corrie, Parker Society, Vol. 27 (Cambridge: Cambridge University Press, 1844), pp. 121-22.

29 See The Zuricb Letters, ed. Hastings Robinson, Parker Society, Vol. 51 (Cambridge: Cambridge University Press, 1845), p. 18, n. 1 and Hopf, Martin Bucer, pp. 82-84.

30 Cardwell, I, 161.

31 Cardwell, I, 185, note.

32 Fuller, IV, 34. 